\title{
The development of the textbook of basical science concept contained ethnoscience
}

\author{
Kiki Fatkhiyani, Ririn Andriani Kumala Dewi * \\ Department of Primary Education, Graduate School of STKIP NU Indramayu. \\ Jalan Raya Kaplongan No. 28, Kecamatan Karangampel, Indramayu 45283, Indonesia \\ * Corresponding Author. E-mail: ririn.akd@gmail.com
}

Received: 6 June 2020; Revised: 18 June 2020; Accepted: 12 July 2020

\begin{abstract}
Most textbooks highlight the content of learning material rather than the application of the concept in life, so that only a few students are less aware of the importance of the concept of science to the scientific events or general phenomenon in daily life. There are still a few textbooks that associate the learning material with scientific events or phenomenon that occur in daily life. This research was conducted to develop the textbook of the basic science concepts contained ethnoscience. The formulation of the problem in this research is about how the characteristics and feasibility of the textbook of the basic science concepts contained ethnoscience for PGSD student. The research method used is the R\&D research method. The research subjects were 22 STKIP NU Indramayu students who took basic science concept of lectures. The instruments used were expert validation sheets and questionnaires. The research plan begins with initial data collection, field studies, making the textbook of basic concepts contained ethnoscience, then proceed with expert validation by the validators using the developed expert validation instrument. After going through the revision of the validators regarding textbook, a trial of the textbook was developed for students by using a questionnaire to find out the user's response to the feasibility of the textbooks of basic science concepts contained ethnoscience. The results of expert validation are 94.5, and it's categorized very validly. Meanwhile, the results of user responses questionnaire are 81.60 with a very decent category.
\end{abstract}

Keywords: textbook, ethnoscience, basical science concepts

How to Cite: Fatkhiyani, K., \& Dewi, R. (2020). The development of the textbook of basical science concept contained ethnoscience. Jurnal Prima Edukasia, 8(2), 156-165. doi:https://doi.org/10.21831/jpe.v8i2.32237

\section{Introduction}

The success of learning to achieve competence based on the applicable curriculum, is not only determined by human resource factors such as teachers and lecturers or the selection of models, methods and learning strategies used but also from the selection of teaching materials used to support improving the quality of learning. Teaching materials play an important role in increasing the effectiveness of learning. This is evidenced from research conducted by Arsanti (2018, p. 71) concerning the development of creative writing teaching materials containing religious character education values for PBSI FKIP UNISSULA students stated the textbooks have been developed are effective in improving creative writing skills students.

Another study conducted by Nailiyah et al. (2016, p. 265) concerned the Development of Ethnographic-Based Thematic Science Module in Jember Regency on Tobacco Cultivation Themes in Middle Schools stated the module could increase the effectiveness of learning by $85 \%$.

Based on the results of research conducted above prove that teaching materials have an important role in improving the quality of learning. However, the problem found in the field is the lack of innovative teaching materials that can support the fulfillment of the competencies set by higher education institutions. Especially textbooks on basical concepts of IPA. It is still rare for textbooks to integrate science concepts with natural phenomenon or common events in daily life that occur in local society.

Indonesia is an archipelago, diverse ethnic and cultural and customs circulating in the community. Therefore, people in Indonesia still tend to believe in myths that exist without being based on science. This certainly affects the quality of education in Indonesia. According to the results of the PISA survey 
in 2018 (Schleicher, 2019, p. 8), science education in Indonesia is still at level 1a with 9th place from the bottom.

Based on Organisation for Economic Co-operation and Development (2019); Schleicher (2019, p. 113) percentage of students able to perform tasks at each level or above (OECD average) is $94,1 \%$ which means Indonesia is at level 1a. Level 1a means students are able to use basic or everyday content and procedural knowledge to recognise or identify explanations of simple scien tific phenomena. With support, they can undertake structured scientific enquiries with no more than two variables. They are able to identify simple causal or correlational relationships and interpret graphical and visual data that require a low level of cognitive demand. Level 1a students can select the best scientific explanation for given data in familiar personal, local and global contexts.

Indonesian students have not been able to reach the highest level. The highest level is at level 6, students can draw on a range of interrelated scientific ideas and concepts from the physical, life, and earth and space sciences and use content, procedural and epistemic knowledge in order to offer explanatory hypotheses of novel scientific phenomena, events and processes or to make predictions. In interpreting data and evidence, they are able to discriminate between relevant and irrelevant information and can draw on knowledge external to the normal school curriculum. They can distinguish between arguments that are based on scientific evidence and theory and those based on other considerations. Level 6 students can evaluate competing designs of complex experiments, field studies or simulations and justify their choices.

One of the efforts to achieve the scientific ability of students at level 6 is applying the textbook of basical concept of IPA contained ethnoscience in learning and the teaching. In that book, the learning material is explained contextually. Such as the anatomy of the human body, also explained phenomena that occur in daily life that are considered unnatural and cannot be explained scientifically such as "tindihan", "cegukan", "jarem" and so on. The phenomena mentioned above can be explained scientifically. So students can understand the phenomenon based on scientific facts not based on the perspective of the local community.

STKIP NU students as prospective teachers only understand the science material conceptually so that they cannot understand phenomena scientifically and apply their understanding in daily life. The use of textbooks of the basical concepts of IPA contained ethnoscience in learning is expected to provide significant changes to the learning outcomes.

According to Handayani (2018); Prastowo (2011) generally, many educators only provide monotonous teaching materials. The use of teaching resources used so far only comes from textbooks or articles downloaded from the internet or other references. This makes students become bored in participating the learning process, so the learning process becomes ineffective and inefficient.

Based on the results of a survey conducted to 22 students of PGSD STKIP NU Indramayu regarding the content of the desired textbooks as many as 59.09\% strongly agreed and as much as $40.91 \%$ agreed to want a textbook that integrates science concepts with daily science experience. Thus, students want contextual textbooks that do not only contain science material but also that link science concepts with science that occur in daily life.

According to Irawati and Saifuddin (2018, p. 98) Preparation of textbooks are adapted to the curriculum, written and designed based on students' needs, uses communicative language, refers to competencies that must be achieved, arranged for instructional processes and has a feedback mechanism from students. In general it can be said that these textbooks can develop the potential of students into independent learners.

One of the efforts to fulfill the needs and desires of students in improving the quality of learning for the achievement of learning objectives is to develop textbooks of the basical concepts of IPA contained ethnoscience. The term of ethnoscience comes from the Greek, word ethnos means nation and the word scientia from Latin, it means knowledge. According to (Sudarmin, 2014), ethnoscience means the knowledge possessed by a nation or more precisely a certain ethnic group or social group. There are three areas of ethnoscience studies: culture as a model for classifying environmental or social situations, structures used to classify the environment both physical and social, and a set of principles for creating and constructing events to gather individuals or many people.

The development of ethnoscience teaching materials is not only able to increase the effectiveness of learning but also to develop the character of conservation. This is based on research conducted by Rahayu and Sudarmin (2015, p. 925) on the Development of an Integrated Science Module Based on 
Jurnal Prima Edukasia, 8 (2), 2020 - 158

Kiki Fatkhiyani, Ririn Andriani Kumala Dewi

Ethnoscience Energy Themes in Life to Embed Student Conservation Souls. From these studies, the results obtained the level of conservation character of students is at the level of starting to develop and the results of student questionnaire analysis also showed the results begin to develop.

Based on the background above, the research on the development of textbooks of basical concepts of IPA contained ethnoscience for PGSD students needs to be done. The characteristic of this developed textbook is ethnoscience content in the learning material that is used as the trust of the local community. The contents of ethnoscience in question can be natural phenomena or events commonly occur in daily life. By the existence of this textbook is expected to provide scientific treasures, especially in learning activities and generally in the world of education.

\section{Method}

This research used a Research and Development study. This research produced the textbook of the basical concepts of IPA contained Ethnoscience. The development research procedure refers to the Sugiyono development research model (Sugiyono, 2010, p. 298).

The study was conducted at STKIP NU Indramayu in 2019/2020 academic year. The subjects were 22 students of Elementary School Teacher Education study programs who took the basical concepts of IPA lectures. This development research procedure is modified according to the needs. The procedure for the development of thevtextbook of basical concept of IPA contained ethnoscience is described below.

Analysis of Potential and Problems

Potential and problem analysis was carried out to determine the potential and problems contained in PGSD STKIP NU Indramayu study program. Analysis of potentials and problems is carried out with literature review and interviews with lecturers who teach basical concept of IPA and some students about matters relating to teaching, learning, and curriculum materials.

Data Collection

Data collection in this study was carried out using interviews, validation sheets, and questionnaires. The data obtained in the form of the results of a literature review and interview of the initial conditions of lectures before using textbooks of basical concept of IPA contained ethnoscience. From the validation sheet, the data of the feasibility of the textbook was validated by expert validators and the response of the use of textbooks of basical concept of IPA contained ethnoscience was known by distributing questionnaires to the PGSD students.

\section{Textbook Design}

The design of textbooks of basical concepts of IPA contained ethnoscience is compiled based on an analysis of potentials and problems that have been carried out previously. The data from the reviewers and interviewers are taken into consideration to compile textbooks of the basical concepts of IPA contained ethnoscience. The characteristic of this textbook is including the events or phenomena related to ethnoscience and also can increase students' insights about the explanation of concepts and scientific events occurred in daily life and based on scientific literacy competencies so that PGSD students can develop their scientific literacy abilities. The development of textbooks is based on the UNESCO format and Semester Learning Plan and adjusted to the scope of science subject curriculum in primary schools.

\section{Textbook Design Validation}

Expert validation or expert judgment is carried out to obtain suggestions for improvement as well as an assessment of the experts (validators) of the textbook design of the basical concepts of IPA contained ethnoscience (draft 1). The validation of devices and instruments is focused on material, language, graphics, and textbook development. If the validation result of the expert is valid and feasible, a draft 2 is obtained and does not need to be revised, but if the results show that the textbook is not valid and feasible, then another revision must be made.

Revised Textbook Design

Based on the results of the validation conducted by an expert validators, it was obtained suggestions or input on the developed textbook. The results of the validation are the basis for the improvement 
of the textbook design developed (draft 2). It aims to produce textbooks that are suitable for use in basical concept of IPA learning and teaching.

Trial of Textbooks

A trial was conducted to reflect on the validated textbooks (draft 2). The trial was conducted on 22 students of the PGSD STKIP NU Indramayu were taken randomly and heterogeneously. The trial results are analyzed and revised to get the textbooks to be printed.

\section{Revised Textbook Design}

Based on the results of the trial of the textbooks and the students responses as users about the lack of textbooks developed, then the textbook could be revised before printing on a large scale. The technique is used to collect the data is check list technique. It measure the validity of the textbook of the basical concepts of IPA contained ethnoscience. It validated by expert validators and the questionnaire technique was carried out to determine students' responses to the use of textbook of basical concepts of IPA contained ethnoscience in learning. Meanwhile, the data collection instruments used were validation sheets and response questionnaires.

The data analysis technique is used to test the textbook feasibility by considering input from experts as validators and students as users. The measurement of response questionnaires is using the Likert scale method. The results of this analysis are used to make improvements to the textbook developed.

Before the research instrument is used, the instrument is tested first to determine its validity and reliability. The questionnaire validation test uses Pearson product moment correlation and the reliability test uses Cronbach-Alpha. The results of the validity test were obtained from 15 statements were used, there are 10 valid statements and 5 invalid statements with $n=27$ and $r_{\text {table }}=0.381$. While the results of the reliability of the questionnaire trial obtained $\alpha=0.944$. It means the reliability of the response questionnaire trials is categorized as high.

The benchmark of success in this study is the textbook of the basical concepts of IPA contained ethnoscience is stated valid and feasible based on the results of the assessment of experts as validators and students responses questionnaire of the using of the textbooks of basical concept of IPA contained ethnoscience as users.

\section{Results and Discussion}

The characteristic of the textbook of basical Concept of IPA Contained Ethnoscience

The development of this textbook of basical concept of IPA contained ethnoscience has its own characteristics, including the selection of material has been adjusted to the scope of the science curriculum in elementary schools and semester learning plans, Contextual material content is related to a phenomenon that is happening or has already happened related to the material being studied. Visually, the display at this point is showed in Figure 1.

POJOK FENOMENA

\begin{tabular}{|l|} 
Tahun 2019 populasi ular kobra di Indonesia meningkat terutama di pulau \\
jawa, hal itu disebabkan karena perubahan musim akibat pemanasan global \\
yang mempengaruhi laju perputaran angin. Musim hujan akan datang kalau \\
sudah berhembus angin muson barat, yang membawa uap air yang melintasi \\
lautan. Jika suhu bumi semakin panas, hembusan angin akan berubah
\end{tabular}

Figure 1. The phenomenon that occur

Ethnoscience is closely related to the contextual learning. Based on the recapitulation results of the student response questionnaire on indicators of contextual science learning, the percentage of results obtained was $90.91 \%$ with a very decent category. This means that students like learning directly related to daily life. According to Lestari and Fitriani (2016, p. 31) ethnoscience is one type of contextual teaching and learning. Ethnoscience is a cross-disciplinary science that connects human or cultural anthropology with the study of science.

Contextual learning can facilitate students in understanding the concepts of science in their application to the life of science in the environment. According to Priyani et al. (2019); Surdin (2018) 
Contextual Teaching and Learning (CTL) is a learning system that matches the performance of the brain, to construct patterns that embody meaning, by linking the academic content with the context of everyday life of the learners. It is important to apply so that the information received is not only stored in shortterm memory, which is easily forgotten, but can be stored in long-term memory so that it will be appreciated and applied in the job task.

This is supported by research conducted by Marliani et al. (2018, p. 35) revealed that the application of contextual teaching and learning approaches to science subjects in primary schools can improve learning outcomes with mastery learning by $97 \%$. Likewise in research conducted by Neftyan et al. (2018, p. 446) stated that the application of contextual teaching and learning approaches in physics subjects obtained an average value of $\mathrm{N}$-gain of 0.73 included in the high category. The research shows the contextual teaching and learning approach has an influence in improving learning outcomes.

In other studies, based on literature studies conducted by Haryanto and Arty (2019, p. 7), it can be concluded that contextual teaching and learning is a learning approach that can be applied as an effort to improve high-level thinking skills and self-efficacy of students. Learning is done by linking material with real life contexts, so that students are able to analyze, evaluate, and create. The ability of students to solve problems in life can then improve self-efficacy.

The material learning in the textbook developed contained ethnoscience. It contains phenomenon or myths believed in local people. It can be used as material for developing scientific literacy. It is showed in Figure 2.

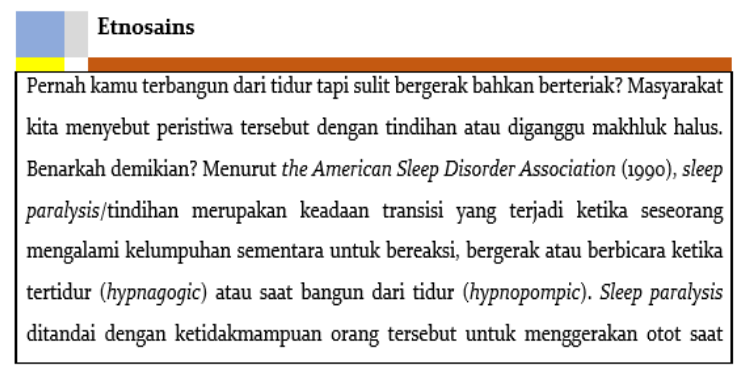

Figure 2. Ethnoscience Content

Through ethnoscience, students can learn the culture or beliefs that exist in society based on a scientific perspective. it was also revealed by Fasasi $(2017$, p. 39) that ethnoscience Interaction clearly facilitates the easiness with which students across cultural borders into school (western) science thus encouraging meaningful learning of science.

According to Pertiwi and Firdausi (2019, p. 123), the efforts can be done to increase scientific literacy in Indonesian students by applying ethnoscience approach in learning and teaching. The ethnoscience approach is a strategy for creating learning environments and designing learning experiences that integrate culture as part of the learning process. The importance of learning using a local cultural approach and the environment or ethnoscience approach as a source of learning so that the learning process is more meaningful for students and can affect the improvement of students' learning outcomes.

Besides that, ethnoscience-based learning can also remind students of cognitive abilities and critical thinking, it is stated in the research Arfianawati et al. (2016, p. 46) stated the contribution of the application of ethnoscience-based Chemistry learning models to the improvement of cognitive abilities is equal to $40,1 \%$ and an increase in students' critical thinking by $17 \%$. The same thing was also stated in the study of Sudarmin et al. (2017) ethnoscience-based modules can improve classical cognitive abilities by $90.63 \%$, and an increase in learning outcomes categories based on $\mathrm{N}$-gain scores. The influence of the ethnoscience approach module is also able to improve students' entrepreneurial character. Based on these results it can be concluded that the ethnoscience approach is effective for improving student learning outcomes and entrepreneurship. In another study conducted by Ariningtyas and Wardani (2017, p. 895), ethnoscience can effectively improve the ability of scientific literacy.

In other studies conducted by Usman et al. (2019, p. 154), the ethnoscience based module on materials substance and its characteristics that are used have a positive influence which makes the experimental class students have higher learning outcomes than the control class which means there are differences between both of them. This proves that the ethnoscience approach embedded in the module until the development of ethnics-based modules on science material becomes a solution that can overcome the problems that have existed so far, which can improve student learning outcomes, especially 
on substance material and characteristics and provide information to students that science materials what they learn turns out to be related to the environment and culture around them, with this module students become motivated, active and independent in learning so that their learning outcomes improve.

Practical activities or simple experiments conducted in the laboratory or outside to develop psychomotor abilities. As shown in in Figure 3.

AKTIVITAS

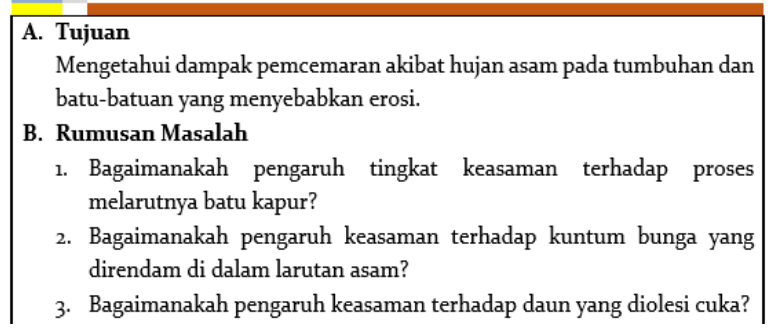

\section{Figure 3. Practical Activities}

The existence of practical activities or simple experiments in this textbook in addition to improving cognitive abilities but also expected to improve students' psychomotor abilities in learning activities. Although cognitive abilities are most often measured in learning, measurement of other domains such as psychomotor abilities is also important to achieve learning outcomes holistically.

The activity section in this textbook can be used as a guide for students in preparing and conducting practical activities or simple experiments in the laboratory or outside. The existence of clear instructions or practical instructions can guide students in carrying out practicum activities step by step to get the desired experimental results so that the learning objectives can be achieved properly. Similar to the practical instructions in this textbook, a scientific-based module in which there is a guide to practicum activities can also be used as a guide in conducting practical activities. This is in line with the results of Marianingsih et al. (2019, p. 375) research, it stated that the application of contextual scientific-based modules can improve students' psychomotor abilities by $80.4 \%$ with a good category.

Exercises is used as feedback to find out the improvement in student learning outcomes. The questions in exercises part are presented in each chapter to measure the level of student understanding of the material has been learned through the textbook. The intended level of understanding includes three domains of learning outcomes, namely the cognitive, affective and psychomotor domains. The exercises in the textbook are objective tests in the form of multiple choice and description tests.

In addition to the contents of the book has been explained above. The writing of this textbook uses serif type fonts. Serif fonts are traditionally considered to be easier to read than sans serif fonts because they are recommended in Merriam-Websster's manual fot writers and editors (2003). Indeed, most books (including e-books) are printed in serif fonts, and the APA Publication Manual (2009) also recommends serif fonts when sending manuscripts for publication (Moret-Tatay \& Perea, 2011).

According to Hojjati and Muniandy (2014, p. 163) the Times New Roman font type, which is one of the serif type fonts, is easier to read for documents or printed books. Besides using the right type of font to facilitate the readability of printed books. Space also determines comfort in reading a book or printed document. In the textbook developed, the space used is $1.5 \mathrm{pt}$. It is done to facilitate students in reading science textbooks of basical concept of IPA contained ethnoscience.

According to Hojjati and Muniandy (2014, p. 162) stated spaces are useful because it helps the eye to find the font block as a group, and also supports the reader quickly to find the beginning of each line. In typography, control of space between words is an important part of page design. Loose easing has a tendency to influence the page flow and reduce readability.

The Feasibility of the Textbook of Basical Concept of IPA Contained Ethnoscience

The feasibility test of the textbook of basical concepts of IPA contained ethnoscience is done in 3 ways, those are:

\section{Expert Validation}

The results of expert validation of textbooks of the basical concepts of IPA contained ethnoscience can be seen in Table 1 . 
Jurnal Prima Edukasia, 8 (2), 2020 - 162

Kiki Fatkhiyani, Ririn Andriani Kumala Dewi

Table 1. Recapitulation of the Result of Validation Expert

\begin{tabular}{|c|c|c|c|c|c|}
\hline \multirow{2}{*}{ No. } & \multirow{2}{*}{ Aspect } & \multicolumn{2}{|c|}{ Average Value of Validators } & \multirow{2}{*}{ Value } & \multirow{2}{*}{ Category } \\
\hline & & 1 & 2 & & \\
\hline 1. & Feasibility Content & 93,8 & 93,8 & 93,8 & Very Valid \\
\hline 2. & Language & 100 & 100 & 100 & Very Valid \\
\hline 3. & Presentation & 87,5 & 100 & 93,8 & Very Valid \\
\hline 4. & Devlopment & 100 & 100 & 100 & Very Valid \\
\hline 5. & Ethnoscience & 100 & 100 & 100 & Very Valid \\
\hline 6 & Graphic & 75 & 83,3 & 79,2 & Very Valid \\
\hline \multicolumn{4}{|c|}{ Average Value of Validators } & 94,5 & Very Valid \\
\hline
\end{tabular}

The achievement in every aspect of the 20 indicators obtained an average value of 2 expert validators is 94.5 with a very valid category. The aspects of language, development and ethnoscience approach get the highest score of 100. While the lowest aspect scores are the graphic aspect with a value of 79.2. Nevertheless, this aspect is still in the category of very valid.

Before the textbook of basical concepts of IPA contained ethnoscience is tested on the user, there several inputs from the validators are the textbook has been compiled by the author as a whole is seen based on aspects of the criteria are considered to be good enough and deserve to be used as a textbook for students. However, there are a few shortcomings, for example textbooks have not become a mediator in improving psychomotor readers. Could the author add exercises or work projects based on hands on activity in the textbooks in an effort to improve psychomotor readers. The existence of this textbook can provide more knowledge and understanding of the science material for readers (both students and general). However, for practical activities still needs to be added more.

Based on input from expert validation regarding the contents of the textbook of basical concept of IPA contained ethnoscience, this textbook has several revisions including adding practical activities and project work. The addition of practical activities about classifying of the living things in chapter 1 . It talks about morphology, physiology, classification of animals and plants; Proving the volume and capacity of the Lungs in chapter 2. It talks about anatomy and physiology of the human body; Knowing the impact of pollution due to acid rain on plants and rocks that cause erosion in chapter 3. It talks about ecosystem; Making Hand Sanitizer; and the effect of calor on change of form.

From the addition of the five practical activities after testing the textbooks to the users, it was obtained from 22 students that $9.09 \%$ stated strongly agree and $77.27 \%$ stated agreed with the use of textbooks of basical concept of IPA contained ethnoscience could develop skills in designing and conducting experiments. This is possible because in the implementation of practical activity, the students are taught how to formulate problems, use tools, take measurements, interpret data, and make communicating by making reports as a product.

The addition of practical activities in the textbooks can also affect the development of students' scientific process abilities, this is supported by research conducted by Satriani et al. (2018, p. 146) stated the mastery of science process exclusion after practical activities is at high category with an average value of 75.89 and there is a positive and significant relationship between the implementation of the practical activities and science process skills with a coefficient value of 0.442 is in a fairly strong relationship.

\section{User Response Questionnaire}

User response questionnaire is given to 22 students of elementary school teacher education courses who take basical concept of IPA lectures. Table 2 showed a recapitulation of the response results based on the acquisition of scores on the statements submitted.

Table 2. Recapitulation of User Response Questionnaire Results

\begin{tabular}{clll}
\hline No. & \multicolumn{1}{c}{ Aspect } & Value & \multicolumn{1}{c}{ Category } \\
\hline 1. & Feasibility Content & 86,36 & Very Feasible \\
2. & Language & 80,68 & Feasible \\
3. & Graphics & 80,11 & Feasible \\
4. & Development & 79,26 & Feasible \\
& Average Value & 81,60 & Very Feasible \\
\hline
\end{tabular}


The average value of user responses to 4 aspects of assessment with 10 statements that is equal to 81.60 with a very decent category. The aspect of material coverage with the highest value is 86.36 with the very feasible category and the aspect gets the lowest value is the development aspect with a value of 79.26 but still in the feasible category. To find out more clearly in seeing the comparison of the highest and lowest graphs based on the results of the user response questionnaire can be seen in Figure 4.

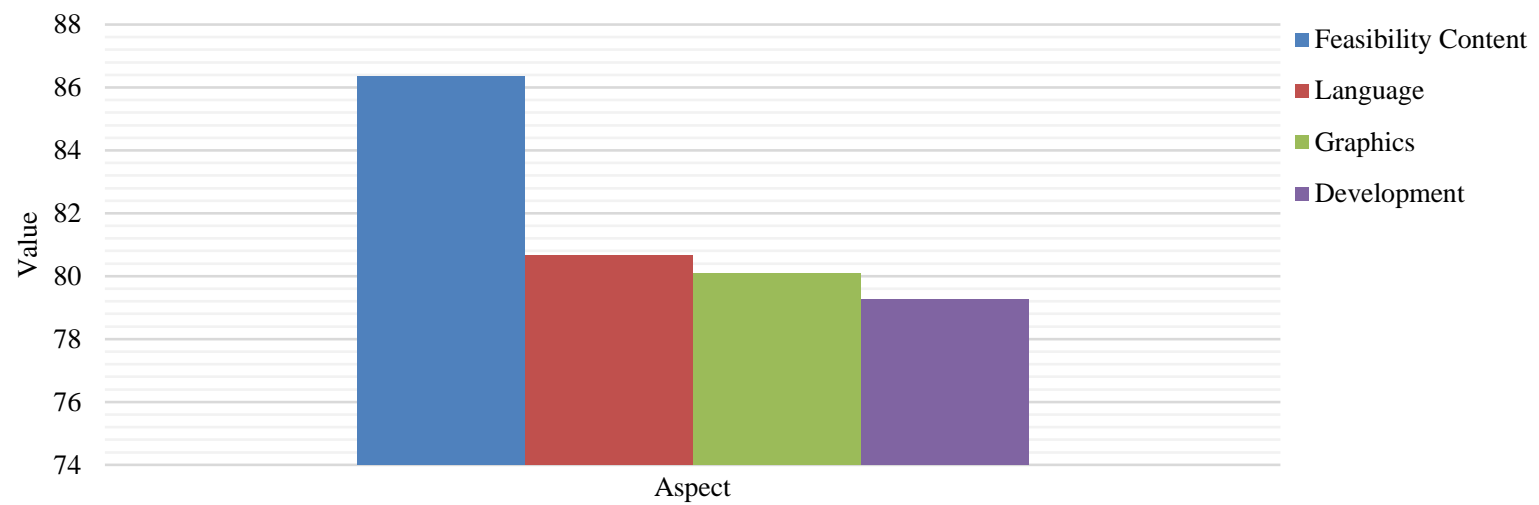

Figure 4. Recapitulation of Users Response Questionnaire Results

The results of users responses revealed that the aspect of feasible content gained the highest score of 86.36. This is caused by the feasible content of the textbook of basical concepts of IPA contained ethnoscience was made based on the analysis of student needs and based on the analysis of science material in elementary school based on the 2013 curriculum. Therefore, the material learning suitable with the student needs and can be accepted by them.

In addition, the language aspect also gained the second highest score of 80.68 with the appropriate category. According to Atun et al. $(2015$, p. 3$)$ the use of language in textbooks will affect the ability of students to understand a lesson. If students can understand the language used in textbooks, students can understand the contents of the textbook as well. Therefore, the use of language in textbooks needs to be considered and adjusted to certain rules that include spelling, grammar, and sentence structure.

The development aspect got the lowest score among the other three aspects. That is because 4 students expressed their disagreement with the statement stating that the use of textbooks of the basical concepts of IPA contained Ethnoscience could develop skills in planning and conducting experiments. Based on the data, the textbook of basical concept of IPA contained ethnoscience must be revised first, especially in experimental and practical activities which are easier to do because not all students of the primary education study program have done a practical activities or previous experiment. The situation occurred because PGSD study program students came from various majors at the high school / vocational level.

Based on the results of previous research conducted by Dewi and Rukmini (2019, p. 45) revealed that 33 students of PGSD STKIP NU Indramayu graduated from Social and Language major, only 5 students graduated from Natural Sciences, so students were not accustomed to doing activities relating to the development of mathematical logical intelligence such as conducting experiments, making predictions, testing hypotheses, observing and solving problems related to numbers. These caused students to be less trained in questions related to logical-mathematical intelligence.

\section{Conclusion}

The conclusion of this study is the textbook of the basical concepts of IPA has its characteristics. Its characterictic is ethnoscience content. The contents of ethnoscience could be myths and natural phenomena or events that are prevalent in daily life. The results of the content validity test by the experts obtained an average value of 2 validators was 94.5 with a very valid category. The results of student responses was 81.6 with a very decent category. Based on these results, it can be concluded that the textbook of the basical concepts of IPA contained ethnoscience for PGSD students is appropriate for publication and use in learning and teaching. 
Jurnal Prima Edukasia, 8 (2), 2020 - 164

Kiki Fatkhiyani, Ririn Andriani Kumala Dewi

\section{References}

Arfianawati, S., Sudarmin, M., \& Sumarni, W. (2016). Model pembelajaran kimia berbasis etnosains untuk meningkatkan kemampuan berpikir kritis siswa. Jurnal Pengajaran MIPA, 21(1), 46-51. https://doi.org/10.18269/jpmipa.v21i1.669

Ariningtyas, A., \& Wardani, S. (2017). The effectiveness of student's worksheet containing ethnoscience in hydrolysis of salt to increase the science literacy of high school student. International Journal of Science and Research (IJSR), 6(7), 890-896. https://www.ijsr.net/get_abstract.php?paper_id=ART20175268

Arsanti, M. (2018). Pengembangan bahan ajar mata kuliah penulisan kreatif bermuatan nilai-nilai pendidikan karakter religius bagi mahasiswa prodi PBSI, FKIP, UNISSULA. KREDO : Jurnal Ilmiah Bahasa Dan Sastra, 1(2). https://doi.org/10.24176/kredo.v1i2.2107

Atun, N. M., Fuad, M., \& Rusminto, N. E. (2015). Penggunaan bahasa indonesia dalam buku teks matematika kelas VII terbitan Kemdikbud. Jurnal Kata (Bahasa, Sastra, Dan Pembelajarannya), 3(2). http://jurnal.fkip.unila.ac.id/index.php/BINDO1/article/view/10202

Dewi, R. A. K., \& Rukmini, P. (2019). The effect of thematic learning by using a scientific approach to increase the multiple intelligence of students. Jurnal Prima Edukasia, 7(1), 40-46. https://doi.org/10.21831/jpe.v7i1.24326

Fasasi, R. A. (2017). The impact of ethnoscience instruction on cognitive achievement in science. International Journal of Education and Learning, 6(2), 33-42. https://doi.org/10.14257/ijel.2017.6.2.03

Handayani, M. (2018). Developing thematic-integrative learning module with problem-based learning model for elementary school students. Jurnal Prima Edukasia, 6(2), 166-176. https://doi.org/10.21831/JPE.V6I2.14288

Haryanto, P. C., \& Arty, I. S. (2019). The application of contextual teaching and learning in natural science to improve student's HOTS and self-efficacy. Journal of Physics: Conference Series, 1233, 012106. https://doi.org/10.1088/1742-6596/1233/1/012106

Hojjati, N., \& Muniandy, B. (2014). The effects of font type and spacing of text for online readability and performance. Contemporary Educational Technology, 5(2), 161-174. https://doi.org/10.30935/cedtech/6122

Irawati, H., \& Saifuddin, M. F. (2018). Analisis kebutuhan pengembangan bahan ajar mata kuliah pengantar profesi guru Biologi di Pendidikan Biologi Universitas Ahmad Dahlan Yogyakarta. BIO-PEDAGOGI, 7(2), 96-99. https://jurnal.uns.ac.id/pdg/article/view/27636

Lestari, N., \& Fitriani, F. (2016). Physics education based ethnoscience: Literature review. Proceeding of ICMSE, 3(1). https://journal.unnes.ac.id/sju/index.php/icmse/article/view/13371

Marianingsih, P., Asmawati, A., Agrania, S., \& Leksono, S. M. (2019). Kemampuan afektif dan psikomotor siswa melalui penerapan modul berbasis saintifik kontekstual keanekaragaman buah di Banten. Prosiding Seminar Nasional Pendidikan FKIP, 2(1), 735-744. http://jurnal.untirta.ac.id/index.php/psnp/article/view/5780

Marliani, S., Rengganis, I., \& Djumhana, N. (2018). Penerapan pendekatan contextual teaching and learning (CTL) untuk meningkatkan hasil belajar pembelajaran IPA. Jurnal Pendidikan Guru Sekolah Dasar, 3(1), 35-42. https://doi.org/10.17509/jpgsd.v3i1.14018

Moret-Tatay, C., \& Perea, M. (2011). Do serifs provide an advantage in the recognition of written words? Journal of Cognitive Psychology, 23(5), 619-624. https://doi.org/10.1080/20445911.2011.546781

Nailiyah, M. R., Subiki, S., \& Wahyuni, S. (2016). Pengembangan modul IPA tematik berbasis etnosains kabupaten jember pada tema budidaya tanaman tembakau di SMP. Jurnal Pembelajaran Fisika, 5(3), 261-269. http://jurnal.unej.ac.id/index.php/JPF/article/view/4071

Neftyan, C. C. A., Suyanto, E., \& Suyatna, A. (2018). The influence of learning using contextual teaching and learning approach to physics learning outcomes of high school students. International Journal of Advanced Engineering, Management and Science, 4(6), 446-450. https://doi.org/10.22161/ijaems.4.6.3 
Organisation for Economic Co-operation and Development. (2019). PISA 2018 results (Volume I). OECD. https://doi.org/10.1787/5f07c754-en

Pertiwi, U. D., \& Firdausi, U. Y. R. (2019). Upaya meningkatkan literasi sains melalui pembelajaran berbasis etnosains. Indonesian Journal of Natural Science Education (IJNSE), 2(1), 120-124. https://doi.org/10.31002/nse.v2i1.476

Prastowo, A. (2011). Panduan kreatif membuat bahan ajar inovatif. DIVA Press.

Priyani, Y., Nofiana, M., \& Julianto, T. (2019). The effect of contextual teaching and learning (CTL) model towards the student's science literacy on bio diversity in MAN 2 Banyumas. Jurnal Kiprah, 7(1), 1-12. https://doi.org/10.31629/kiprah.v7i1.996

Rahayu, W. E., \& Sudarmin, S. (2015). Pengembangan modul IPA terpadu berbasis etnosains tema energi dalam kehidupan untuk menanamkan jiwa konservasi siswa. Unnes Science Education Journal, 4(2). https://doi.org/10.15294/usej.v4i2.7943

Satriani, S., Taiyeb, A. M., \& Mu'nisa, A. (2018). Analisis hubungan pelaksanaan praktikum dengan keterampilan proses sains dan hasil belajar biologi peserta didik SMA Negeri di Kota Bulukumba. Seminar Nasional Biologi. https://ojs.unm.ac.id/semnasbio/article/view/6975

Schleicher, A. (2019). PISA 2018: Insights and interpretations. OECD Publishing. https://www.oecd.org/pisa/PISA 2018 Insights and Interpretations FINAL PDF.pdf

Sudarmin, Febu, R., Nuswowati, M., \& Sumarni, W. (2017). Development of ethnoscience approach in the module theme substance additives to improve the cognitive learning outcome and student's entrepreneurship. Journal of Physics: Conference Series, 824, 012024. https://doi.org/10.1088/1742-6596/824/1/012024

Sudarmin, S. (2014). Pendidikan karakter, etnosains dan kearifan lokal. Unnes Semarang.

Sugiyono. (2010). Metode penelitian kuantitatif kualitatif dan $R \& D$. Alfabeta.

Surdin, S. (2018). The effect of contextual teaching and learning (CTL) models on learning outcomes of social sciences of the material of forms the face of the earth on class VII of junior high school. International Journal of Education and Research, 6(3). https://www.ijern.com/journal/2018/March-2018/08.pdf

Usman, N., Rahmatan, H., \& Haji, A. G. (2019). Ethno-science based module development on material substance and its characteristics to improve learning achievement of junior high school student. International Journal of Innovation in Science and Mathematics, 7(3), 148-157. https://www.ijism.org/administrator/components/com_jresearch/files/publications/IJISM_845_F INAL.pdf 